\title{
Geographical Variation of Mandible Size and Shape in the Ryukyu Wild Pig (Sus scrofa riukiuanus)
}

\author{
Hideki ENDO, Seishi MAEDA ${ }^{1)}$, Daishiro YAMAGIWA ${ }^{1)}$, Masamichi KUROHMARU ${ }^{1)}$, Yoshihiro HAYASHI ${ }^{1)}$, Shôsaku \\ HATTORI $^{2)}$, Yaetsu KUROSAWA ${ }^{3)}$ and Kazue TANAKA ${ }^{4)}$ \\ Department of Zoology, National Science Museum, Shinjuku-ku, Tokyo 169, 'Department of Veterinary Anatomy, Graduate School of \\ Agricultural and Life Sciences, The University of Tokyo, Bunkyo-ku, Tokyo 113, ${ }^{2}$ Amami Branch Laboratory, Institute of Medical \\ Science, The University of Tokyo, Kagoshima 894-15, ${ }^{3)}$ Cattle Museum, Maesawa-cho, Iwate 029-42, and ${ }^{4}$ Department of Animal \\ Breeding, Faculty of Agriculture, Tokyo University of Agriculture, Setagaya-ku, Tokyo 159, Japan
}

(Received 17 June 1997/Accepted 29 August 1997)

ABSTRACT. We measured adult mandibles of Ryukyu wild pigs from Amami-Oshima, Kakeroma, Okinawa, Ishigaki and Iriomote Islands. The size cline was not statistically recognized among the populations of Nansei Islands. The Ishigaki population was significantly larger than Iriomote one in mandible length. Some measurement ratios indicated that the ramus is enlarged laterally and that the body of mandible is dorso-ventrally developed in Ishigaki and Iriomote populations. The Amami-Oshima mandibles were relatively smaller than those of Okinawa and Iriomote populations in length item of body of mandible. These results will contribute to the zoo-archaeology on the historical change of size and shape in the island populations, and to the evolutionary biology on the morphological adaptation of this animal.—KEY wORDS: geographical variation, mandible, osteometry, swine (Ryukyu wild pig).

The Ryukyu wild pig (Sus scrofa riukiuanus) is distributed in Amami-Oshima, Kakeroma, Tokunoshima, Okinawa, Ishigaki and Iriomote Islands of the Nansei Islands, in the southernmost part of Japan (Fig. 1). We clarified the growth pattern and sexual dimorphism of skulls in the Iriomote population [4]. Imaizumi [9] and some researchers $[8,17,18]$ dealt with osteometrical data of this animal from the view of taxonomy and archaeology. However, the morphological variation has remained unclear among island populations. Size cline in the Nansei Islands and adaptational significance of size and shape variation in each island should be examined from many specimens of Ryukyu wild pig.

\section{MATERIALS AND METHODS}

We used 322 mandibles of Ryukyu wild pigs from Amami-Oshima, Kakeroma, Okinawa, Ishigaki and Iriomote Islands, which have been stored in the Department of Animal Breeding, Faculty of Agriculture, Tokyo University of Agriculture, and the Department of Zoology, the National Science Museum, and the Department of Veterinary Anatomy, Faculty of Agriculture, The University of Tokyo (Fig. 1).

The method for determining age was essentially based on previous reports according to the eruption and attrition pattern [4, 6]. We selected 95 mandibles of Age groups IV and $\mathrm{V}$ as adult specimens [4], and used them for osteometry from the entire collection. The mandibles were evaluated by 14 measurements (Table 1). Measurements were carried out with a vernier caliper to the nearest $1 \mathrm{~mm}$. Most measurements were performed according to the methods of Driesch [2], while some other items were based on Duerst
[3] (Table 1).

Sex was determined by 2 measurement values, CA1 and CA2. As the two measurement values were expected to show two perfectly separate ranges, we regarded the group with a larger canine as male and the group with a smaller one as female according to the previous study $[4,6]$.

For LA, the statistical significance of differences between males and females was determined in each population by Student's $t$-test to demonstrate the sexual dimorphism. The differences in the LA and some measurement ratios to LA were also statistically examined among populations to clarify the geographical variation of size and shape.

\section{RESULTS}

The range of CA1 and CA2 in males and females for each population are represented in Table 2 . We arrange the locality and sex composition of the specimens in Table 3.

The mean value and standard error of 14 measurements of each population are given in Table 4. Some samples were partially broken, therefore, the number of specimens measured did not agree with the total number of specimens for a few items.

Significant differences between sexes in LA were shown in all islands except for Kakeroma population. Significant differences in LA and some measurement ratio to LA among populations are arranged in Table 5.

\section{DISCUSSION}

The absolute growth pattern of cranium profile length and LA reached a plateau in Age group IV and V in Iriomote population [4]. LA were found to highly correlate with 


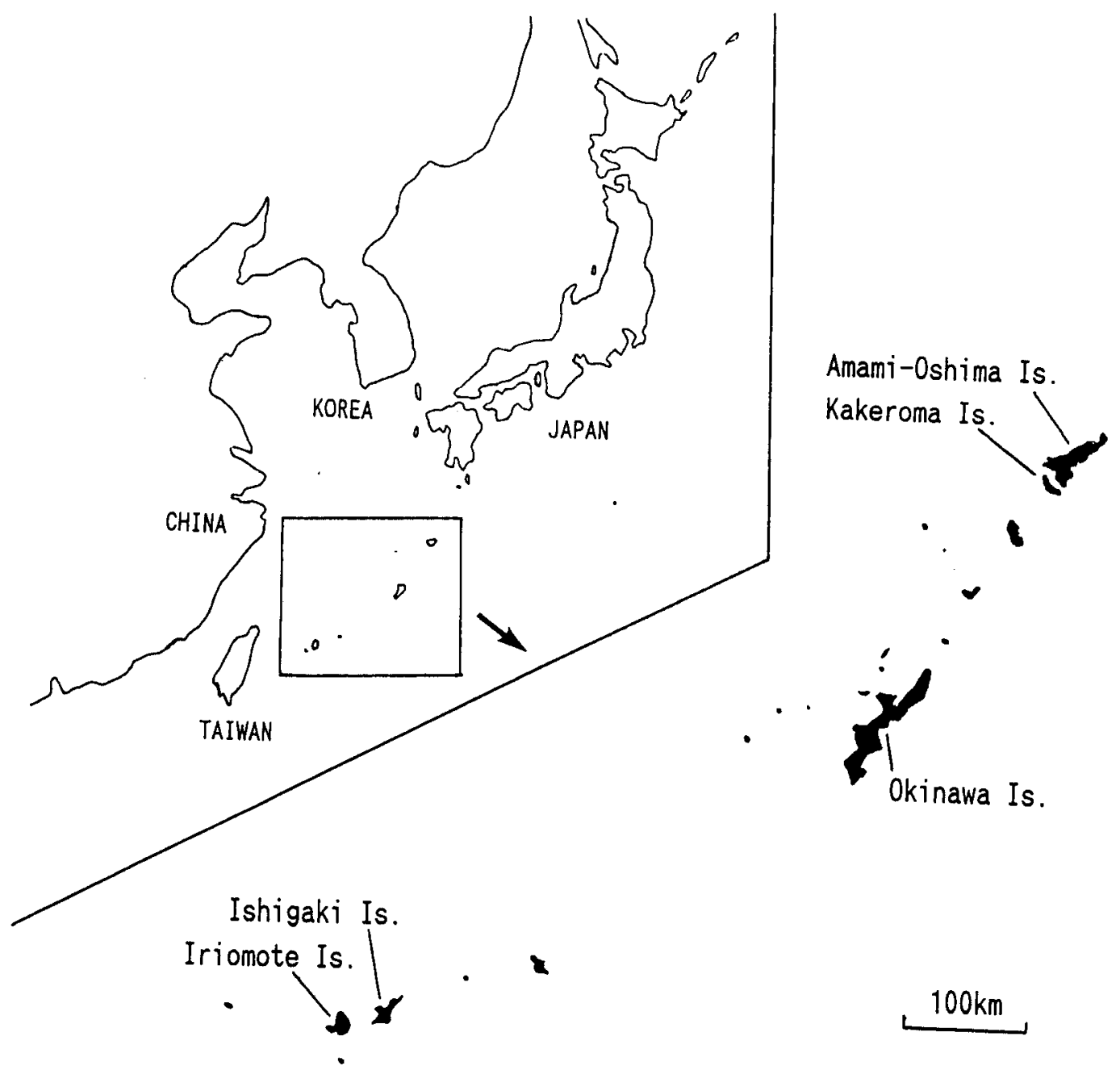

Fig. 1. Map of the Nansei Islands showing localities of wild pig specimens used in this study.

Table 1. List of the measurements and their abbreviations ${ }^{\text {a) }}$

\begin{tabular}{lc}
\hline Length from the angle & LA \\
Length from the condyle & LC \\
Aboral height of the vertical ramus & AHR \\
Oral height of the vertical ramus & OHR \\
Middle height of the vertical ramus & MHR \\
Height of the mandible at $\mathrm{M}_{1}{ }^{\mathrm{b})}$ & $\mathrm{HM}$ \\
Length of symphysis ${ }^{\mathrm{c})}$ & $\mathrm{LS}$ \\
Length between condylon mediale and coronion $^{\mathrm{d})}$ & LCC \\
Length of cheektooth row, $\mathrm{M}_{3}-\mathrm{P}_{2}$ & LPM \\
Breadth of two halves between the condyle processes & BCP \\
Breadth of two halves between the most lateral & BLP \\
$\quad$ points of the two angles & \\
Breadth of two halves between the coronoid processes & BRP \\
Breadth of the mandible across the outer & BM \\
$\quad$ borders of $\mathrm{M}_{1}^{\mathrm{e}}{ }^{\mathrm{e}}$ & \\
Thickness of ramus at $\mathrm{M}_{1}{ }^{\mathrm{f}}$ ) & TR \\
Length of canine & CA1 \\
Length of canine alveolus & CA2
\end{tabular}

a) The measurements without footnote were based on Driesch [2]. b) Synonym of Höhe des Unterkiefers in der Mitte von $\mathrm{M}_{1}$ [3]. c) Synonym of Lenge der Symphyse [3]. d) Synonym of Condylocoronoidlänge [3]. e) Synonym of Breite des Unterkiefers auf der Höhe des $M_{1}$ [3]. f) Synonym of Breite je einer Mandibel auf der Höhe des $\mathrm{M}_{1}[3]$.
TR

CA1

(b)

Table 2. The range of size of canine $(\mathrm{mm})$ and the sex determination from these values

\begin{tabular}{lcc}
\hline & CA1 & \\
\hline Locality & Male & Female \\
\hline Amami-Oshima & $30-41$ & $11-18$ \\
Kakeroma & 29 & $14-15$ \\
Okinawa & $29-49$ & $12-20$ \\
Ishigaki & $36-39$ & $15-23$ \\
Iriomote & $31-38$ & $11-23$ \\
\hline
\end{tabular}

)


body weight and/or head and body length in Japanese wild pigs [1]. Therefore, it is suggested that the measurement data (Table 4) represent the typical size and shape of each population of Ryukyu wild pig.

LA of Ishigaki population is the most noteworthy. Ishigaki mandibles have a significant difference in LA size from the specimens of many islands. These data are consistent with those of the preliminary measurement in Ishigaki skulls [9]. Imaizumi [9] mentioned the distribution of hybrid population between Ryukyu wild pigs and domesticated ones with much larger size in Ishigaki Island. However, because the hybrid animals or population have been potentially established and more or less installed in the entire regions of Japan since the beginning of artificial breeding and maintenance of Sus scrofa, the large size in this island should be dependent on other specific causes. It

Table 3. Locality and sex composition of mandible specimens

\begin{tabular}{lcc}
\hline Locality & Male & Female \\
\hline Amami-Oshima & 17 & 10 \\
Kakeroma & 2 & 3 \\
Okinawa & 13 & 15 \\
Ishigaki & 3 & 6 \\
Iriomote & 9 & 17 \\
\hline
\end{tabular}

is useful to compare the animal size between Ishigaki and Iriomote populations, because the two islands are located in almost the same latitude and are not distinguished in the geological influences. We suggest the area and topography of Ishigaki Island are obviously different from those of Iriomote Island and may have an adaptational influence on the large size in this island.

It was suggested that the geographical cline in size may be present from Amami-Oshima to Iriomote populations except Ishigaki specimens [9]. Certainly Iriomote mandibles are significantly smaller than Amami-Oshima mandibles in male and than Kakeroma ones in female, but the size cline is not statistically recognized among the populations of Nansei Islands in this study. The discussion in the evolutionary relationship between Ryukyu and Japanese wild pigs has been partially based on the clinal analysis [9]. However, morphological variation within the Ryukyu wild pigs should be more prudently analyzed to confirm the taxonomical relationship among Sus scrofa populations.

The ratios LC/LA, HM/LA and female BCP/LA show the specific shape to Ishigaki and Iriomote populations. It indicates that the ramus is enlarged laterally and that the body of mandible is dorso-ventrally developed in Ishigaki and Iriomote populations. LS/LA in male and LPM/LA in female indicate that the Amami-Oshima mandibles are obviously different in shape from those of Okinawa and

Table 4. The mean value (mm) and standard error (SE) of measurements of mandible of various islands

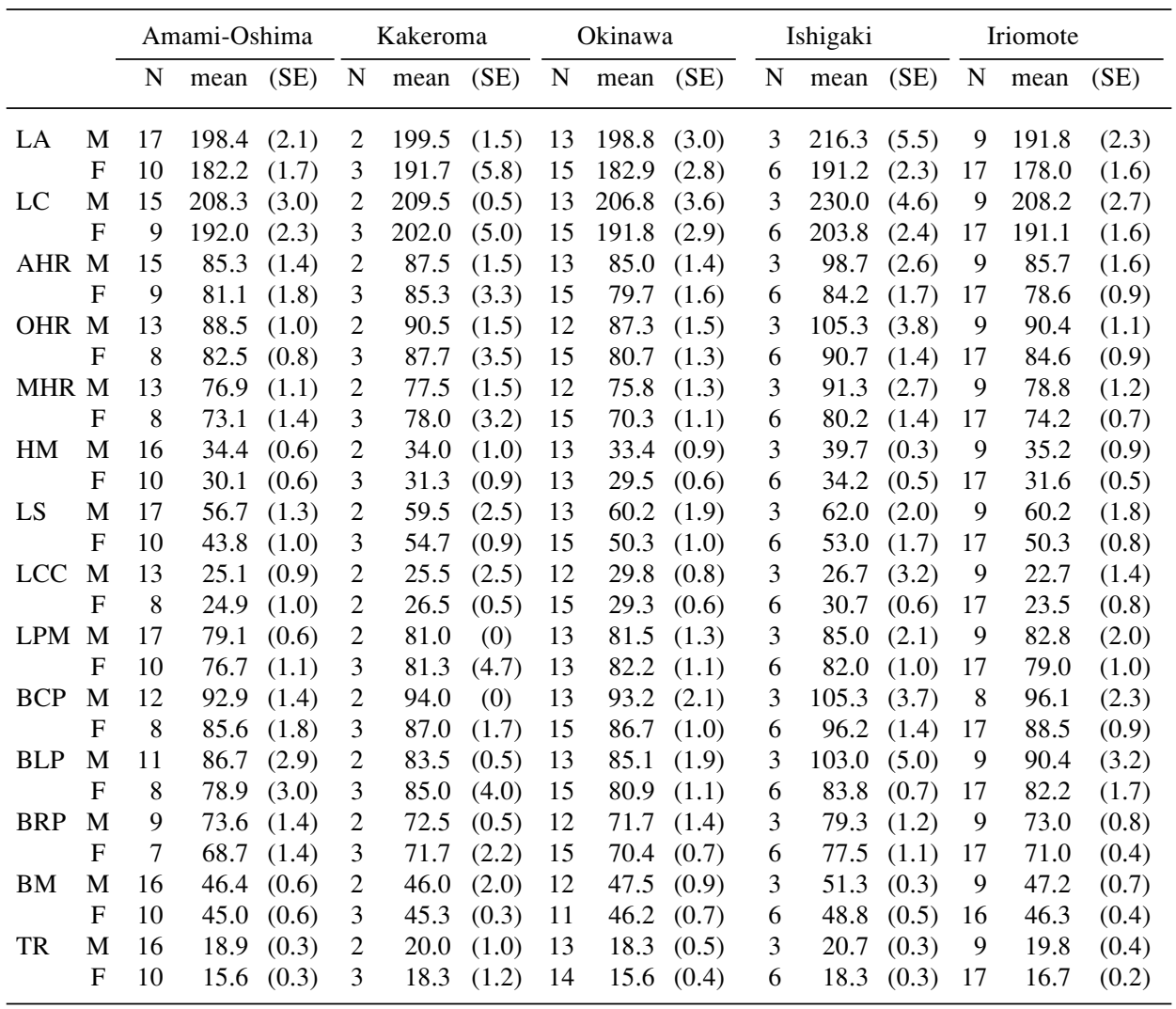

$\mathrm{N}$ : Number of specimens measured in each item. M: Male. F: Female. 
Table 5. Significant difference between islands in LA and each measurement ratio to LA

\begin{tabular}{|c|c|c|c|c|c|c|c|c|c|}
\hline $\begin{array}{l}\text { A. LA } \\
\text { (male) } \\
\text { Kakeroma }\end{array}$ & $\begin{array}{c}\text { Amami-Oshima } \\
-\end{array}$ & Kakeroma & Okinawa & Ishigaki & $\begin{array}{l}\begin{array}{l}\text { E. LS/LA } \\
\text { (male) } \\
\text { Kakeroma }\end{array}\end{array}$ & $\begin{array}{c}\text { Amami-Oshima } \\
-\end{array}$ & Kakeroma & Okinawa & Ishigaki \\
\hline Okinawa & - & - & & & Okinawa & + & - & & \\
\hline Ishigaki & + & - & + & & Ishigaki & - & - & - & \\
\hline Iriomote & + & - & - & + & Iriomote & + & - & - & - \\
\hline (female) & Amami-Oshima & Kakeroma & Okinawa & Ishigaki & (female) & Amami-Oshima & Kakeroma & Okinawa & Ishigaki \\
\hline Kakeroma & + & & & & Kakeroma & + & & & \\
\hline Okinawa & - & - & & & Okinawa & - & - & & \\
\hline Ishigaki & + & - & - & & Ishigaki & - & - & - & \\
\hline Iriomote & - & + & - & + & Iriomote & + & - & - & - \\
\hline $\begin{array}{l}\text { B. LC/LA } \\
\text { (male) } \\
\text { Kakeroma }\end{array}$ & $\begin{array}{c}\text { Amami-Oshima } \\
-\end{array}$ & Kakeroma & Okinawa & Ishigaki & $\begin{array}{l}\text { F. LPM/LA } \\
\text { (male) } \\
\text { Kakeroma }\end{array}$ & $\begin{array}{c}\text { Amami-Oshima } \\
-\end{array}$ & Kakeroma & Okinawa & Ishigaki \\
\hline Okinawa & - & - & & & Okinawa & - & - & & \\
\hline Ishigaki & - & - & + & & Ishigaki & - & - & - & \\
\hline Iriomote & + & + & + & - & Iriomote & + & - & - & - \\
\hline (female) & Amami-Oshima & Kakeroma & Okinawa & Ishigaki & (female) & Amami-Oshima & Kakeroma & Okinawa & Ishigaki \\
\hline $\begin{array}{l}\text { Kakeroma } \\
\text { Okinawa }\end{array}$ & - & - & & & Kakeroma & $\begin{array}{l}- \\
+\end{array}$ & - & & \\
\hline $\begin{array}{l}\text { Okinawa } \\
\text { Ishigaki }\end{array}$ & $\begin{array}{l}- \\
+\end{array}$ & - & + & & $\begin{array}{l}\text { Okinawa } \\
\text { Ishigaki }\end{array}$ & $\begin{array}{l}+ \\
-\end{array}$ & - & _- & \\
\hline Iriomote & + & + & + & - & Iriomote & + & - & - & - \\
\hline $\begin{array}{l}\text { C. AHR/LA } \\
\text { (male) } \\
\text { Kakeroma }\end{array}$ & $\begin{array}{c}\text { Amami-Oshima } \\
-\end{array}$ & Kakeroma & Okinawa & Ishigaki & $\begin{array}{l}\text { G. BCP/LA } \\
\text { (male) } \\
\text { Kakeroma }\end{array}$ & $\begin{array}{c}\text { Amami-Oshima } \\
-\end{array}$ & Kakeroma & Okinawa & Ishigaki \\
\hline Okinawa & - & - & & & Okinawa & - & - & & \\
\hline Ishigaki & - & - & - & & Ishigaki & - & - & - & \\
\hline Iriomote & - & - & - & - & Iriomote & + & - & + & - \\
\hline (female) & Amami-Oshima & Kakeroma & Okinawa & Ishigaki & (female) & Amami-Oshima & Kakeroma & Okinawa & Ishigaki \\
\hline Kakeroma & - & & & & Kakeroma & - & & & \\
\hline Okinawa & - & - & & & Okinawa & - & - & & \\
\hline Ishigaki & - & - & - & & Ishigaki & + & + & + & \\
\hline Iriomote & - & - & - & - & Iriomote & - & + & + & - \\
\hline $\begin{array}{l}\text { D. HM/LA } \\
\text { (male) } \\
\text { Kakeroma }\end{array}$ & $\begin{array}{c}\text { Amami-Oshima } \\
-\end{array}$ & Kakeroma & Okinawa & Ishigaki & $\begin{array}{l}\text { H. BM/LA } \\
\text { (male) } \\
\text { Kakeroma }\end{array}$ & $\begin{array}{c}\text { Amami-Oshima } \\
-\end{array}$ & Kakeroma & Okinawa & Ishigaki \\
\hline Okinawa & - & - & & & Okinawa & - & - & & \\
\hline Ishigaki & + & - & + & & Ishigaki & - & - & - & \\
\hline Iriomote & + & - & + & - & Iriomote & + & - & - & - \\
\hline (female) & Amami-Oshima & Kakeroma & Okinawa & Ishigaki & (female) & Amami-Oshima & Kakeroma & Okinawa & Ishigaki \\
\hline Kakeroma & - & & & & Kakeroma & - & & & \\
\hline Okinawa & - & - & & & Okinawa & - & - & & \\
\hline Ishigaki & + & + & + & & Ishigaki & + & + & - & \\
\hline Iriomote & + & + & + & - & Iriomote & + & + & - & - \\
\hline
\end{tabular}

$+\mathrm{P}<0.05$. - No significant difference.

Iriomote populations. It is suggested that Amami-Oshima population may grow weakly in length item in body of mandible. No significant difference is not demonstrated in AHR/LA, the height measurements of ramus.

Some reports $[7,8,17,18]$ pointed out that Ryukyu wild pig is obviously smaller in body size than Japanese one. In multivariate analysis, we distinguished Amami-Oshima mandibles from those of Southeast Asian populations in both size and shape vectors [7]. From the data, it can be estimated the entire Sus scrofa population has large variation in skull size and shape. Imaizumi [9] considered Ryukyu wild pig as an independent species from Japanese wild pig from the evaluation of some non-metric characters. However, the entire Sus scrofa population with large geographical variations should not be easily split in the species level only from a few bone characters. We suggest that the species split between Ryukyu and Japanese populations [9] may be based on the unreliable evaluation of only a few morphological characters.

We dealt with genetic studies on blood group antigen as Ea and polymorphisms of serum protein as transferrin and $6 P G D$, and recognized the genetic differences among wild pig populations in Japan [11-14]. However, the data has not been consistent between blood group antigens and serum 
proteins.

It has been suggested that this animal was introduced to Nansei Islands by ancient people [8, 16, 18]. However, fossil records appeared to indicate that the animal migrated to the islands in Würm epoch when a land bridge connected the continent and Nansei Islands [5]. In this conflict problem on the origin of Ryukyu wild pig, the polymorphism in restriction endonuclease cleavage patterns (RECP) of mitochondrial DNA was detected among wild, native and domesticated pig populations in southeast Asia [15, 19-21], and Komatsu [10] confirmed the difference of RECP between Ryukyu and Japanese populations and suggested that the Ryukyu populations may be relics of Asian continent ancestor. The RECP and the sequence data of various regions in mitochondrial DNA [19] may be useful in the examination of the origin of some populations and their genetic distance. However, in the future, only the morphological data including the present results contribute to the zoo-archaeology on the historical change of size and shape in the island Sus scrofa populations, and to the evolutionary biology on the morphological adaptation of this animal.

ACKNOWLEDGEMENTS. We are grateful to $\mathrm{Mr}$. Kensaku Obana of Tokyo University of Agriculture, to Dr. Kyoumi Yamazaki of Iwaki Junior College (Fukushima, Japan) and to Dr. Kishio Maeda of Nara University of Education (Nara, Japan) for their valuable assistance in the osteology. We also thank Dr. Masamitsu Hanai of the Agency for Cultural Affairs (Tokyo, Japan), Miss Tomoko Ogoh and Miss Tomoko Yoshida of National Science Museum, for their kind information on the Nansei Islands and the specimens of Ryukyu wild pig.

\section{REFERENCES}

1. Abe, M. 1989. Fundamental studies of animal remains of prehistoric Japan (3): Estimation of the growth stage and the body size of wild boar (Sus scrofa leucomystax) by observation and measurements of crania. Anthrop. Rep. 48: 27-63 (in Japanese with English abstract).

2. Driesch, A. 1976. A Guide to the Measurement of Animal Bones from Archaeological Sites, Harvard Univ., Cambridge.

3. Duerst, J. U. 1926. Vergleichende Untersuchungsmethoden am Skelett bei Säugern. pp. 125-530. In: Handbuch der Biologischen Arbeitsmethoden, Abt. 7, Urban \& Schwarzenberg, Berlin.

4. Endo, H., Kurohmaru, M. and Hayashi, Y. 1995. An osteometrical study of the cranium and mandible of Ryukyu wild pig in Iriomote Island. J. Vet. Med. Sci. 56: 855-860.

5. Hasegawa, Y. 1980. Notes on vertebrate fossils from late Pleistocene to Holocene of Ryukyu islands, Japan. Quaternary Research 18: 263-267 (in Japanese with English abstract).

6. Hayashi, Y., Nishida, T., Mochizuki, K. and Seta, S. 1977. Sex and age determination of the Japanese wild boar (Sus scrofa leucomystax) by the lower teeth. Jpn. J. Vet. Sci. 39: 165-174 (in Japanese with English abstract).

7. Hayashi, Y., Nishida, T., Hashiguchi, T. and Simamora, S. 1983. Morphological similarities of the mandible between Indonesian native pig and seven types of Asian wild boar. Rep. Soc. Res. Native Livestock 10: 140-145 (in Japanese with English abstract).

8. Hayashida, S. 1960. Studies on wild boar and dog found at shell-mounds in the Amami-Oshima Archipelago. J. Anthrop. Soc. Nippon 68: 96-115 (in Japanese with English abstract).

9. Imaizumi, Y. 1973. Taxonomic study of the wild boar from Ryukyu Islands, Japan. Mem. Natl. Sci. Mus. 6: 113-129 (in Japanese with English abstract).

10. Komatsu, M. 1995. Nihon no Inoshishi to Buta. Animal Husbandry 49: 65-68 (in Japanese).

11. Kurosawa, Y., Tanaka, K., Nishida, T. and Cyril, H. W. 1986. Blood groups and biochemical polymorphisms of wild pigs, Sus scrofa cristatus in Sri Lanka. Rep. Soc. Res. Native Livestock 11: 143-154 (in Japanese with English abstract).

12. Kurosawa, Y. and Tanaka, K. 1988. Electrophoretic variants of serum transferrin in wild pig populations of Japan. Anim. Genetics 19: 31-35.

13. Kurosawa, Y., Tanaka, K. and Oishi, T. 1989. Genetic variability of the Ryukyu wild pig (Sus scrofa riukiuanus) population in Iriomote island. Mammalian Sci. 29: 13-21 (in Japanese with English abstract).

14. Kurosawa, Y. and Tanaka, K. 1991. PGD variants in several wild pig populations of East Asia. Anim. Genetics 22: 357360.

15. Lan, H. and Shi, L. 1993. The origin and genetic differentiation of native breeds of pigs in southwest China. Biochem. Genetics 31: 51-60.

16. Naora, N. 1937. On the pig in the prehistoric age of Japan. $J$. Anthrop. Soc. Tokyo 52: 286-296 (in Japanese).

17. Semba, T. 1960. On the bones of wild boar from the Shimotabaru Shell-mound in the Haderuma Island, Loochoo Islands. Quart. J. Anthrop. 7: 57-60 (in Japanese with English abstract).

18. Semba, T. 1964. On the skulls of wild boars from the Iriomote Island, Loochoo Islands. Rep. Committee Foreign Sci. Res., Kyushu Univ. 2: 251-256 (in Japanese with English abstract).

19. Takeda, K., Onishi, A., Ishida, N., Kawakami, K., Komatsu, M. and Inumaru, S. 1995. SSCP analysis of pig mitochondrial DNA D-loop region polymorphism. Anim. Genetics 26: 321-326.

20. Watanabe, T., Hayashi, Y., Ogasawara, N. and Tomita, T. 1985. Polymorphism of mitochondrial DNA in pigs based on restriction endonuclease cleavage patterns. Biochem. Genetics 23: 105-114.

21. Watanabe, T., Hayashi, Y., Kimura, J., Yasuda, Y., Saitou, N., Tomita, T. and Ogasawara, N. 1986. Pig mitochondria DNA: Polymorphism, restriction map orientation, and sequence data. Biochem. Genetics 24: 385-396. 